\title{
(e) interface
}

comunicação, saúde, educação

https://www.interface.org.br

eISSN 1807-5762

\section{Resenhas}

\section{Saúde, doença e produção de conhecimentos}

Health, disease and knowledge production

Salud, enfermedad y producción de conocimientos
Jonatan Sacramento ${ }^{(a)}$

<jonatansacramento@gmail.com> (a) Pós-Graduando do Programa de
Pós-Graduação em Ciências Sociais
(Doutorado), Instituto de Filosofa
e Ciências Humanas, Universidade
Estadual de Campinas. Rua Cora
Coralina, 100, Cidade Universitária,
Barão Geraldo. Campinas, SP, Brasil.

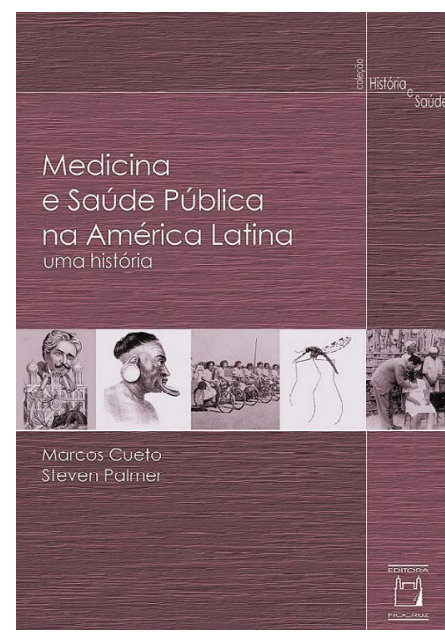

Cueto M, Palmer S. Medicina e Saúde Pública na América Latina: uma história. Rio de Janeiro: Fiocruz; 2016. construção do conhecimento por pessoas, objetos e, mesmo, pelos próprios fatos científicos, a história das ciências e da saúde tem nos mostrado como os processos de produção

Grandes narrativas em saúde são parte da história oficial do Brasil e de vários países do mundo. Enquanto nos trópicos temos os famosos exemplos de Oswaldo Cruz e Carlos Chagas, para citar apenas dois exemplos, na França contamos com Louis Pasteur e, na Inglaterra, com Edward Jenner. Por outro lado, se a historiografia contemporânea tem contribuído para uma análise mais crítica dessas atuaçóes e seus impactos na sociedade, a história da ciência e da saúde, formada por um grupo de pesquisadoras e pesquisadores de diversas instituiçốes e ligados a diversas correntes teóricas, tem conseguido lançar um renovado e problematizador olhar para as análises sobre o tema.

Tomando como central os processos de saúde e doença e a 
científica e de formulação e execução de ações de saúde, por exemplo, condensam não apenas as tensões entre distintos grupos e correntes científicas, como, também, a contingencialidade dos processos políticos e históricos nos quais esses se encontram localizados.

É no bojo desse debate intelectual que a obra "Medicina e Saúde Pública na América Latina - uma história”, dos historiadores Marcos Cueto e Steven Palmer, se encontra. Publicado originalmente em 2015 pela Cambridge University Press, a versão brasileira saiu pela Editora da Fundação Oswaldo Cruz e com tradução de Sérgio Lamarão. Fruto de anos de pesquisa e colaboração entre os dois historiadores, o livro se apresenta como uma síntese da história da Medicina e da Saúde Pública na América Latina desde o século XVII, ao mesmo tempo em que nos brinda com uma análise aquilatada sobre os processos de construção e institucionalização dos conhecimentos médicos e suas instituições no subcontinente.

Composto por cinco capítulos, o livro percorre a história da Saúde Pública na América Latina de meados do século XVII até os dias atuais. O mais significativo, no entanto, é o foco que os autores dão para retomar essa história: contá-la a partir da perspectiva latino-americana, numa análise de caráter relacional, demonstrando como a produção intelectual, a formação e atuação profissional e política das figuras da Saúde Pública latino-americanas estavam em ampla sintonia com a produção e os sistemas intelectuais americanos e europeus. Para os autores, a saúde pública praticada na América Latina já no século XIX se constituía como um campo autônomo e, ao mesmo tempo, internacionalizada, na medida em que estava inserida num fluxo internacional de pesquisa e pesquisadores. No entanto, pontuam os mesmos, percalços também existiram e foram traduzidos por aquilo que Cueto e Palmer chamam de "cultura da sobrevivência" e "saúde na adversidade".

Para eles, ainda que gozando de prestígio e reconhecimento internacional, a saúde pública latino-americana foi construída em cima de medidas sanitárias paliativas, que não tendiam a solucionar os problemas, mas, antes, atenuar suas consequências ${ }^{1}$. No entanto, junto a essa cultura de sobrevivência, convivia também a capacidade nativa em negociar com as políticas de saúde e se adaptar diante de práticas sanitárias hegemônicas, que ignoravam as necessidades e as expertises locais, ao mesmo tempo em que, muitas vezes, se mostravam insuficientes.

Assim, no capítulo I, "Medicina indígena, saúde oficial e pluralismo médico", Cueto e Palmer afirmam que a medicina que se formou na América Latina teria sido o resultado da mistura entre "medicinas nativas", praticadas por indígenas e escravos, com os saberes europeus da época. Nessa interação, o corpo de conhecimentos médicos-sanitários latino-americano se consolidou a partir das universidades, instituiçôes de pesquisa e órgãos corporativos, mas, também, da prática de curandeiros que foram aborvidos pela lógica dos poderes públicos da época.

$\mathrm{Na}$ esteira desses acontecimentos, as "Medicinas nacionais e estados sanitários", nome do capítulo II, se formam em estreita relação. Ao mesmo tempo em que o estabelecimento dos Estados-Nações possibilitou a institucionalização dos sistemas de saúde ao longo do século XIX, as reformas de Saúde e a Saúde Pública foram essenciais em dar forma e consolidar tais estados ${ }^{1}$. Para os autores, a história da América Latina está entrelaçada com a história das doenças, dos sofrimentos, da saúde e da medicina desse mesmo espaço cultural. 
A formação do corpo dos profissionais de saúde daquele século, sobretudo os médicos, possibilitou a conformação de uma elite local e a criação de quadros políticos nacionais que definiram os rumos desses países. A conjunção entre medicina e as ideologias liberal e positivista teve como resultado a formulação de códigos e políticas sanitárias e o desenvolvimento de instituições de saúde e científicas que deram corpo aos novos estados nacionais.

Se, durante o século XIX, a influência europeia na medicina brasileira se dava, especialmente, por meio da bacteriologia alemã e da microbiologia francesa, no começo do século XX, com o início das operações da Fundação Rockfeller em território latinoamericano, a influência americana nas áreas de higiene e saúde pública passaria a dar o tom da ciência médica desenvolvida no continente. Segundo os autores, a medicina tropical, que, para os EUA e a Europa, representava um dispositivo para proteger seus governos coloniais e a oportunidade de se pesquisarem doenças que eram consideradas "raras", para os países latino-americanos e caribenhos, representou um meio de entrelaçar ciência médica, saúde pública e reformas políticas - como bem se observa a partir das ações de controle e combate à febre amarela e a ancilostomíase ${ }^{2,3}$.

É no capítulo III, "A formação da saúde nacional e da internacional”, que os autores lançam luz à atuação da Fundação em território latino-americano, que teve como preocupação não apenas o combate a uma determinada doença, mas, também, possibilitou criar uma rede internacional de instituiçôes, grupos intelectuais e protocolos de saúde. Segundo os autores, a inteligência nativa soube muito bem se utilizar das ações propostas pelos Estados Unidos, de modo a transformar as relaçóes entre a Fundação Rockfeller e os profissionais latino-americanos em “[...] um compromisso reciprocamente definidor e criativo entre uma variedade de atores [...]"1 (p 124). Exemplo claro dessa "cooperação" foi a circulação de profissionais entre os diversos países do continente, tanto para formação quanto para implantação e gestão de projetos de saúde. Além disso, uma certa dose de autonomia latino-americana em relação à expertise americana se traduziu, por exemplo, na singularidade do pensamento eugenista no continente. Nessa lógica, não apenas a raça, como também o ambiente, eram fatores determinantes da conduta social do indivíduo. Assim, as características adquiridas via processos civilizatórios e educacionais poderiam ser herdadas ${ }^{1}$.

A popularização do modelo americano na saúde pública latino-americana se consolidou e se espalhou a partir da criação das escolas de higiene e saúde pública e das escolas de enfermagem, que passaram a oferecer formação específica aos quadros do sanitarismo local e da profissionalização da figura da enfermeira. No Brasil, os exemplos mais claros dessas ações de formação profissional são: o Instituto de Hygiene e Saúde Pública de São Paulo (hoje Faculdade de Saúde Pública da USP) e a Escola de Enfermagem Anna Nery, atualmente ligada à Universidade Federal do Rio de Janeiro ${ }^{4-7}$.

A influência dos EUA na saúde pública dos países latino-americanos foi selada oficialmente no decorrer da Segunda Guerra Mundial, quando tais países firmaram acordos de cooperação técnica e científica com a Fundação Rockfeller. Se, num primeiro momento, a atuação da Fundação se caracterizou como uma intervenção direta, a partir da construção de universidades e institutos que pudessem formar os quadros da saúde em seus próprios países, durante a segunda metade do século XX, 
as ações de saúde foram assumidas e tocadas pelos próprios profissionais locais. No Brasil, o exemplo mais claro é, com certeza, a criação do Serviço Especial de Saúde Pública (SESP) em 1942. O SESP foi responsável por formar e conduzir as açôes de saúde e saneamento no interior do país, aos moldes do que aconteceu nas expediçóes comandadas pelo Instituto Oswaldo Cruz décadas antes ${ }^{8,9}$, mas com o novo elemento da liderança e planejamento dos profissionais brasileiros.

É no quarto capítulo, "Inovaçôes médicas no século XX", que os autores se debruçaram sobre o caráter de tais açôes, sobretudo as que tiveram lugar no Brasil. As expediçôes do Instituto Oswaldo Cruz para combater os problemas de saúde dos sertôes brasileiros, tiveram como objetivo não apenas medidas profiláticas de prevenção e tratamento, mas, também, aquelas de desenvolvimento e combate à pobreza. A missão de Carlos Chagas, que o levou a descobrir e descrever a doença que levaria seu nome, conferiu ao Brasil, e em especial ao Instituto Oswaldo Cruz, um lugar de destaque na ciência internacional, legitimando-o como lugar preferencial para o desenvolvimento da ciência nacional ${ }^{1}$. Ao mesmo tempo, essas iniciativas lograram conformar instituiçôes e práticas governamentais que auxiliaram na consolidação do poder público nacional em âmbitos estaduais e municipais.

Nos anos 1960, com o fracasso das medidas de controle das doenças infectocontagiosas, a saúde pública latino-americana voltou sua atenção para as políticas de saúde sexual e reprodutiva, notadamente nas açốes de planejamento familiar. Dessa vez sob influência direta dos EUA e de órgãos como o Banco Mundial, que estavam preocupados com as altas taxas de natalidade nos países "pobres”. Essa mudança de foco das açôes de saúde e das influências internacionais é um dos temas tratados no capítulo cinco, "Atenção primária à saúde, resposta neoliberal e saúde global na América Latina”, onde os autores apresentam as duas grandes principais mudanças no debate em saúde em nível internacional: a atenção primária em saúde (APS) e atenção primária seletiva à saúde (APSS).

Num contexto de descontentamento com os rumos das açôes de saúde consideradas como verticais e pouco ligadas com os interesses e necessidades locais, a Conferência de Alma Ata, de 1978, apresentou o lema "Saúde para todos até o ano 2000", que pautava suas críticas em três principais fatores: a necessidade de uma aplicação da tecnologia apropriada ao contexto de saúde trabalhado, a oposição ao elitismo médico e a noção de que saúde era um elemento do progresso socioeconômico ${ }^{1}$. Por outro lado, sob a acusação de que a APS apresentava objetivos pouco claros e/ou inalcançáveis ao panorama de saúde mundial, o grupo reunido em torno da APSS se mostrava como um contraponto ao defender uma estratégia de programas de saúde que focassem em quatro portos específicos: o monitoramento do crescimento das crianças, o investimento na difusão das técnicas de reidratação oral, o incentivo à amamentação e os programas de imunização, e que seriam complementadas com a adoção, anos mais tarde, da necessidade da suplementação alimentar, a alfabetização das mulheres e o planejamento familiar.

Segundo Cueto e Palmer, a partir dos anos 1970, a OMS começou a perder a centralidade enquanto órgão de referência internacional em saúde, o que abriu a possibilidade do advento de mecanismos como o Banco Mundial e a Fundação Bill e Melinda Gates, por exemplo, que passaram a (também) dar o tom das discussões sobre os rumos da saúde internacional no contexto do neoliberalismo da época. Ao 
mesmo tempo, o advento das epidemias de HIV/AIDS e das doenças emergentes e reemergentes, tais como a cólera e a dengue, trouxe à tona a necessidade de se pensar a relação saúde e doença para além das fronteiras territoriais, inserindo-as na nova dinâmica econômica e social de fluxos transnacionais. Daí, continuam os autores, surge a ideia de saúde global, que pressupóe que velhos e novos atores tomem o protagonismo das açóes de saúde que devem ter como foco o controle e tratamento das doenças e menos em sua prevenção e/ou nas mudanças dos condicionantes sociais que levam a tais situações.

Para concluir, resta ressaltar, mais uma vez, o tom crítico que os autores assumem nessa refinada análise de história social e intelectual da saúde na América Latina. Sem perder de vista os perigos de se criar ou reforçar as "grandes" narrativas nacionais de mitos fundadores da ciência e da saúde, muito comum no quadro do pensamento político-social e historiográfico latino-americano, Cueto e Palmer, antes, fazem uma dosagem exata entre análise de narrativas de grandes figuras públicas e das densas e delicadas relaçóes onde essas estavam inseridas - levando em consideração não apenas a documentação oficial, mas a história das instituições, cidades, grupos sociais e indivíduos, para a composição de uma análise substancial sobre o tema.

É nesse sentido que os autores afirmam que existe um padrão recorrente na história da medicina e saúde pública na América Latina, onde o intercâmbio de profissionais e sistemas de conhecimento médicos é um exemplo. Tais saberes não seriam adotados de forma acrítica, mas antes, seriam recorrentes também da negociação de saberes e práticas estrangeiras no cotidiano dos profissionais de saúde, e que, por sua vez, mostram como os trabalhos de prevenção, tratamento e reabilitação não deveriam ser tratados como profissóes distintas, mas antes, como aspectos do fazer médico.

Esse protagonismo adaptativo de saberes e tecnologias se enquadra enquanto característica da "saúde na adversidade”, padrão que orienta a prática médica nesses países, segundo os autores. As soluçôes regionais de adaptação das tecnologias de saúde à realidade social local refletem, também, as dinâmicas da cultura de sobrevivência das açóes de saúde pública que, muitas vezes, são estruturadas apenas enquanto respostas a crises sanitárias, e não necessariamente como políticas de saúde de longa duração.

"Medicina e saúde pública na América Latina” não é apenas uma (fina) análise do campo sanitarista no subcontinente, como, também, uma aula de história social e história intelectual que nos permite compreender, a um só tempo, o debate em torno da saúde pública nos países latino-americanos e as complexas relaçôes em jogo no contexto político nacional e nas relaçóes internacionais e redes transnacionais das épocas retratadas, como a própria história desses países.

\section{Direitos autorais}

Este artigo está licenciado sob a Licença Internacional Creative Commons 4.0, tipo BY (https://creativecommons.org/licenses/by/4.0/deed.pt_BR). 


\section{Referências}

1. Cueto M, Palmer S. Medicina e saúde pública na América Latina: uma história. Rio de Janeiro: Fiocruz; 2016.

2. Lowy I. Virus, moustiques et modernité: la fièvre jaune au Brésil, entre science et politique. Paris: Archives Contemporaines; 2001.

3. Palmer S. Gênese da saúde global: a Fundação Rockefeller no Caribe e na América Latina. Rio de Janeiro: Fiocruz; 2015.

4. Mott ML. Gênero, medicina e filantropia: Maria Rennotte e as mulheres na construção da nação. Cad Pagu. 2005; 24:41-67.

5. Rocha HHP. A educação sanitária como profissão feminina. Cad Pagu. 2005; 24:69104.

6. Lopes MJM, Leal SMC. A feminização persistente na qualificação profissional da enfermagem brasileira. Cad Pagu. 2005; 24:105-25.

7. Biernat C, Cerdá JC, Ramaccioti K. La salud pública y la enfermería en la Argentina. Bernal: Universidad Nacional de Quilmes; 2015.

8. Hochman G. A era do saneamento: as bases da política de saúde pública no Brasil. São Paulo: Hucitec, Associação Nacional de Pós-Graduação e Pesquisa em Ciências Sociais; 1998.

9. Lima NT. Um sertão chamado Brasil: intelectuais e representação geográfica da identidade nacional. Rio de Janeiro: IUPERJ/UCAM, Revan; 1998. 